\title{
Removal of Cadmium from Polluted Aqueous Solutions Using Agricultural Wastes
}

\author{
Mohammed Ali I. Al-Hashimi, Manar M. Al-Safar, \\ University of Technology/Building \& Construction Engineering Department/ Environmental \& \\ Sanitary Engineering Branch
}

Rec. 28 Aug, 2012 Accpt. 30 Sept, 2012

\begin{abstract}
Heavy metals are among the most toxic contaminants of surface water. The main sources of heavy metals are industrial wastes from processes such as electroplating, metal finishing, chemical manufacturing, and nuclear fuel processing. Since most of heavy metals are non degradable, these concentration must be reduced to acceptable levels before discharging them into environment. The goal of this research is to examine the ability of different media to reduce the concentration of cadmium ions in aqueous solution. The application of low-cost adsorbents obtained from plant wastes as a replacement for costly conventional methods of removing cadmium ions from wastewater has been reviewed. Langmuir and Freundlich adsorption isotherms found to be applicable to the absorption process and their constants are found. The single component adsorption of heavy metal ions named Cadmium (II) onto powdered activated carbon (PAC), palms karab, rice husks and corncobs from water aqueous solution has been investigated using batch system. In batch tests, the effects of $\mathrm{pH}$, dosage of adsorbent, contact time, initial concentration, mixing (stirring) speed and particle size diameter are studied. The optimum values of $\mathrm{pH}$ is 5.5 , dosage adsorbent is $1 \mathrm{~g}$ sorbent $/ 100 \mathrm{ml}$ of Cd (II), contact time is $30 \mathrm{~min}$, initial concentration is $125 \mathrm{mg} / \mathrm{L}$ and for mixing (stirring) speed is $100 \mathrm{rpm}$.
\end{abstract}

Keywords: Cadmium, Adsorption, Rice husks.

\section{Introduction}

Cadmium is highly toxic non-essential metal which accumulates in the kidneys of mammals and can cause kidney dysfunction (Alloway and Ayres, 1997). Cadmium may interfere with the metallothionein's ability to regulate zinc and copper concentrations in the body. Epidemiological studies have revealed that $\mathrm{Cd}^{2+}$ may contribute to some forms of cancer in humans and low exposures may result in kidney damage (Terry and Ston, 2002). Cadmium is distributed in the environment of Iraq as a result of the use of galvanizing, pigments, stabilizers, thermoplastics, batteries and alloys industries. Moreover, the absence of the direct control from environmental protection agencies on above industries has increased the size of this problem.

Cadmium is responsible for serious damage to the health of humans:

- The most severe from Cd (II) toxicity in humans is "itai- itai", a disease characterized by excruciating pain in the bone (Sulaymon and abdul- Hameed, 2010).
- The harmful effects of cadmium include a number of acute and chronic disorders, such as renal damage, emphysema, hypertension, and testicular etrophy (Tilaki, et al., 2004).

- Cadmium toxicity contributes to a large number of health conditions, including the major killer diseases such as heart disease, cancer and diabetes. Cadmium concentrates in the kidney, liver and various other organs and is considered more toxic than either lead or mercury. It is toxic at levels one tenth that of lead, mercury, aluminum, or nickel (Sayed, et al., 2010).

There are various methods to treat the metal contaminated effluent such as precipitation, reverse osmosis, ion exchange, coagulation, and adsorption. The selection of the treatment methods differ with respect to costs, complexity and efficiency. Among these technologies adsorption is a userfriendly technique for the removal of heavy metal. This process-seems to be most versatile and effective method for removal of

\footnotetext{
* Corresponding author:

Dr. Mohammed Ali I. Al-Hashimi

$凶$ mohashimi2003@yahoo.com
} 
heavy metal if combined with appropriate regeneration steps (Said, 2010).

The term biosorption commonly refers to the passive binding of metal ions or radioactive elements by dead adsorbents. It has to be distinguished from bioaccumulation which is usually understood to be an active, metabolically mediated metalaccumulation process occurring specifically in living organisms (Volesky and Naja, 2005). In the experimental works, the dissolved Cd (II) in aqueous solutions has been selected as the sorbate. The single component adsorption of heavy metal ions named Cadmium (II) onto powdered activated carbon (PAC), palms karab, rice husks and corncobs from aqueous solution has been investigated in batch tests. A good modeling of a dynamic ion-exchange system needs to be based on the proper choice of an equilibrium isotherm to characterize competitive ion exchange (Volesky and Naja, 2005).

Thus, sorption isotherm is a plot between the sorbate uptake $\left(\mathrm{q}_{\mathrm{e}}\right)$ and the final concentration of the residual sorbate remaining in the solution $\left(\mathrm{C}_{\mathrm{f}}\right)$ at equilibrium (Volesky and Naja, 2005).

The Langmuir model can be represented as:

$\mathrm{q}_{\mathrm{e}}=\frac{\mathrm{q}_{\max } b \mathrm{C}_{\mathrm{f}}}{\left(1+b C_{\mathrm{f}}\right)}$

This classical model incorporates two easily interpretable constants: $\mathrm{q}_{\max }$, which corresponds to the maximum achievable uptake by a system; and b, which is related to the affinity between the sorbate and sorbent. The Langmuir constant " $\mathrm{q}_{\max }$ " is often used to compare the performance of biosorbents; while the other constant "b" characterizes the initial slope of the isotherm. Thus, for a good biosorbent, a high $\mathrm{q}_{\max }$ and a steep initial isotherm slope (i.e., high b) are generally desirable [Aksu, et al., 2002].

The Freundlich (Freundlich, 1926) model has been widely used for many years.

The Freundlich equation has the general form:-

$\mathrm{q}_{\mathrm{e}}=\mathrm{K}_{\mathrm{f}} \mathrm{C}_{\mathrm{e}}{ }^{1 / \mathrm{n}}$

Where $\mathrm{K}_{\mathrm{f}}$ and $\mathrm{n}$ are constants and $\mathrm{n}>1$.

(Metcalf and Eddy, 2003), define Freundlich isotherm as follows:-

$\frac{x}{m}=\mathrm{q}_{\mathrm{e}}=\mathrm{K}_{\mathrm{f}} \mathrm{C}_{\mathrm{e}}^{1 / \mathrm{n}}$
Where $\mathrm{x} / \mathrm{m}=$ mass of adsorbate adsorbed per unit mass of adsorbent after equilibrium, $\mathrm{mg}$ adsorbate/g activated carbon $\mathrm{K}_{\mathrm{f}}=$ Freundlich capacity factor, (mg adsorbate/g adsorbent $) *(\mathrm{~L} \text { water } / \mathrm{mg} \text { adsorbate })^{1 / \mathrm{n}}$

$1 / \mathrm{n}=$ Freundlich intensity parameter. Other terms as defined previously.

The constants in the Freundlich isotherm can be determined by plotting $\log (\mathrm{x} / \mathrm{m})$ versus $\log \mathrm{Ce}$ and making use of the linearized form of equation (2) rewritten as:

$\log \left(\frac{x}{m}\right)=\log \mathrm{K}_{\mathrm{f}}+1 / \mathrm{n} \log \mathrm{C}_{\mathrm{e}}$

Sayed, et al., (2010). found the effect of $\mathrm{pH}$ change in the range 1 to 8 on the adsorption of $\mathrm{Ni}$ (II) and Cd (II) on rice straw. The removal of $\mathrm{Ni}$ (II) was about $28 \%$ at a $\mathrm{pH} 1$ while its reached to maximum value $47 \%$ at about $\mathrm{pH}$ 5. Further increase of $\mathrm{pH}$ leads to slight decrease in Ni (II) removal efficiency. The removal percentage of $\mathrm{Cd}$ (II) showed a rapid increase from $25 \%$ to $76 \%$ when the $\mathrm{pH}$ increased from 1 to 6 . Mapolelo and Torto (2004). proved that the biosorption capacity of $\mathrm{Cd}^{2+}, \mathrm{Cr}^{3+}, \mathrm{Cr}^{6+}, \mathrm{Cu}^{2+}, \mathrm{Pb}^{2+}$ and $\mathrm{Zn}^{2+}$ is dependent on $\mathrm{pH}$. For all metal ions they studied, the optimal $\mathrm{pH}$ values are all greater than 5 . The optimal $\mathrm{pH}$ for $\mathrm{Cd}$ and $\mathrm{Pb}$ biosorption is 5.8, while for $\mathrm{Cr}$ (III) and $\mathrm{Pb}$ is 5.2. As the $\mathrm{pH}$ further increases, the biosorption capacity subsequently decreases. The objective of this research was to investigate the optimum conditions of cadmium adsorption.

\section{Materials and Methods:}

- Powdered activated carbon (supplied by BDH chemicals Ltd Poole England, charcoal animal) is used as an adsorbent in the present work.

- Rice husks the chemical composition predominantly contains cellulose (3247\%), hemicellulose (19-27\%) and lignin (5-24\%) [Sayed et al., 2010].

- Palm Karab was collected from Baghdad, Khastawi type.

- Corncobs.

\section{Preparation of the adsorbent:}

The adsorbent was collected from Baghdad. Then sun dried and washed with tap water then rinsed with distilled deionized water several times and thereafter dried temperature of $105^{\circ} \mathrm{C}$ in an oven for 24 hours. Following cut the adsorbent into small pieces by using a housing food processor and through a sieve No.40 (ASTM 
E 11). This was done to remove any large particles and to obtain particles of size less than $(0.425 \mathrm{~mm})$. This fine adsorbent was used in the batch experiments described below. For preservation, it was kept in plastic bags to minimize its contact with humidity.

\section{Preparation the synthetic polluted water sample:}

$1000 \mathrm{mg} / \mathrm{L}$ standard stock solution of Cd (II) was prepared from $\mathrm{Cd}\left(\mathrm{NO}_{3}\right)_{2} \cdot 4 \mathrm{H}_{2} \mathrm{O}$. The required amount of metal salt was dissolved into $1 \mathrm{~L}$ of distilled water and stirred.

\section{Determination of metal ion concen- tration:}

All experiments were after filtration, the synthetic polluted aqueous solution and the resulted samples from each treatment were analyzed for the concentration of Cd (II) by atomic absorption sepectro- photometer (AAS) for concentrations more than $0.1 \mathrm{ppm}$ and the Inductively Coupled Plasma -Mass Spectrometry (ICP-MS) instrument for concentrations less than $0.1 \mathrm{ppm}$. Samples were read three times and the mean values were computed.

\section{Equipment:}

The equipment used in this study are:

1. Housing grinder for grinding the agricultural wastes.

2. Oven for drying the agricultural wastes (model 05,cap 64L,made in England).

3. Glass wares (pipette, conical flasks, volumetric flasks, graduated cylinders and beakers).

4. Disposable Polyethylene bottles for samples.

5. Sieves No. 40, 14, 10, 8 (ASTM E11 Body 316L MESH S-STEEL/ RF, made in Germany).

6. Calibrated $\mathrm{pH}$ meter of type (HANNA instrument, $\mathrm{pH} 211$ Microprocessor $\mathrm{pH}$ meter made in Portugal).

7. Digital Balance 4 decimal degrees (Precisa xp 220A), made in Switzerland.

8. Qualitative filter paper, made in China.

9. Sedimentation Jar Test (Aztec Environmental Control LTD, made in Germany.
10. Atomic absorption sepctrophotometer (GBC 933 plus, made in Australia.

The optimum masses of activated carbon, rice husk, palms karab and corncobs which were $1,1.5,2,2.5 \mathrm{~g}$, respectively, and the optimum $\mathrm{pH}$ of solutions which was 5.5, were used for $\mathrm{Cd}(\mathrm{II})$ in these experiments. These experiments were used to obtain the equilibrium isotherm curves for single metal ions by plotting the mass of solute adsorbed per mass of adsorbent, $\mathrm{q}_{\mathrm{e}}$, against the equilibrium concentration of the solution, $\mathrm{C}_{\mathrm{e}}$, and then to obtain the equilibrium isotherm parameters.

A volume of $100 \mathrm{ml}$ of metal ion solution in different initial concentration of 25-125 $\mathrm{mg} / \mathrm{L}$ was placed in five beakers containing the fixed mass of the sorbent. The beakers were then shaken at a constant speed of 100 rpm in a Jar Test at temperature $25^{\circ} \mathrm{C} \pm 1$ for $30 \mathrm{~min}$. After shaking, the sorbent was separated by filtration through a filter paper $0.425 \mathrm{~mm}$. The filtrate was analyzed for the remaining metal ion concentration by atomic absorption spectrophotometer AAS.

\section{Results and discussion:}

In batch experiments, the influence of the dosage adsorbent, $\mathrm{pH}$ of solution, stirring speed and initial metal ion concentration on the removal of $\mathrm{Cd}(\mathrm{II})$, from solution by adsorption onto powder activated carbon, rice husks, karab and corncobs as an adsorbent was studied.

\section{Effect of pH solution:}

The removal of metal ions from aqueous solution by adsorption is related to the $\mathrm{pH}$ of solution. The first set of tests, therefore, examines the effect of $\mathrm{pH}$ on the effluent concentration.

The low biosorption capacity at $\mathrm{pH}$ values below 4.0 was attributed to hydrogen ions that compete with metal ions on the sorption sites. In other words, at lower $\mathrm{pH}$, due to protonation of the binding sites resulting from a high concentration of protons, the negative charge intensity on the sites is reduced, resulting in the reduction or even inhibition of the binding of metal ions. Similar findings were reported by other researchers (Desi et al., 1998; Emani et al., 2003).

At high $\mathrm{pH}$ values, the removal takes place by adsorption as well as precipitation, due to 
formation of metals hydroxide. This can be explained by the fact that, as the $\mathrm{pH}$ of the solution increased, the $\mathrm{OH}^{-}$ions in the solution increase and form some complexes with metal ions and precipitate as metals hydroxide (Al-Najar, 2009).

In general, it is noticed from Figure (1) that the $\mathrm{Cd}(\mathrm{II})$ uptake of the three types of agro-adsorbents is very low at a $\mathrm{pH}$ of 2.0 . Then, increasing the $\mathrm{pH}$ of the solution from 2 to 4 leads to a rapid increase in the $\mathrm{Cd}(\mathrm{II})$ uptake.

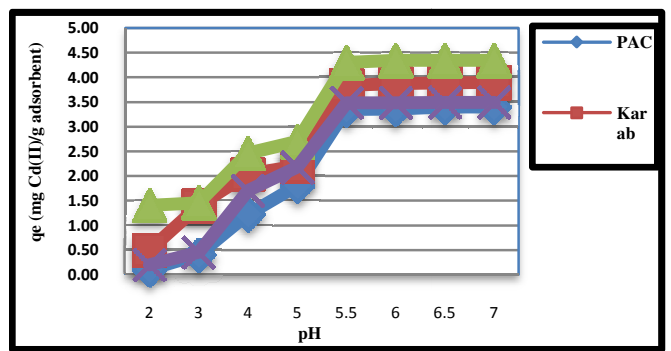

Figure (1): Effect of $\mathrm{pH}$ on $\mathrm{Cd}(\mathrm{II})$ uptake for different materials.

\section{The effect of dosage adsorbent:}

The effect of dosage adsorbent on adsorption of $\mathrm{Cd}(\mathrm{II})$ at a constant adsorbate concentration was studied for the purpose of determining the optimum adsorbents dosage that will bring a best removal. The experiments (batch) started with a dose of 1 to $2.5 \mathrm{~g}$ of sorbent $/ 100 \mathrm{ml}$ cadmium solution of $50 \mathrm{ppm}$ and a contact time of $30 \mathrm{~min}$. The results were plotted, and shown in Figure (2). The metal percent removal increases with a further increase in the quantity of adsorbent the corresponding increase in the observed uptake of $\mathrm{Cd}(\mathrm{II})$.. Also, from Figure (2), the optimum sorbent amount required for efficient treatment can be well noticed.

A crucial parameter for an optimal removal of metal ions in the wastewater.

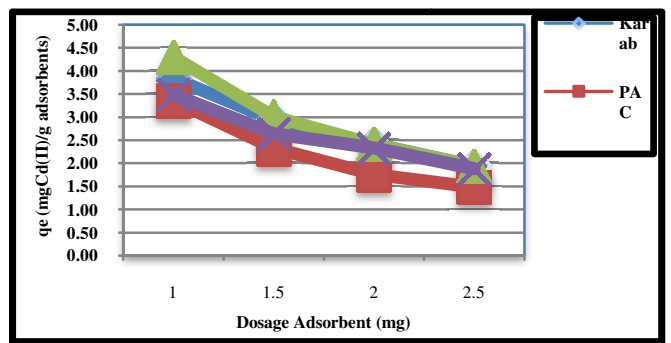

Figure (2): Effect of dosage adsorbent on Cd(II) uptake for different materials.

\section{The effect of contact time:}

The kinetics of metal removal by rice straw was relatively fast within $5 \mathrm{~min}$ and during the first hour was remarkably changed with time. The equilibrium time was taken as $30 \mathrm{~min}$ for further experimental measurements, the results are shown in Figure (3).

In sorption process, equilibrium time is a function of many factors, such as type of adsorbent (number and kind of sorption sites), size and form of adsorbent, physiological state of adsorbent (active or inactive, free or immobilized), as well as the metal involved in the sorption system (Cossich et al., 2002).

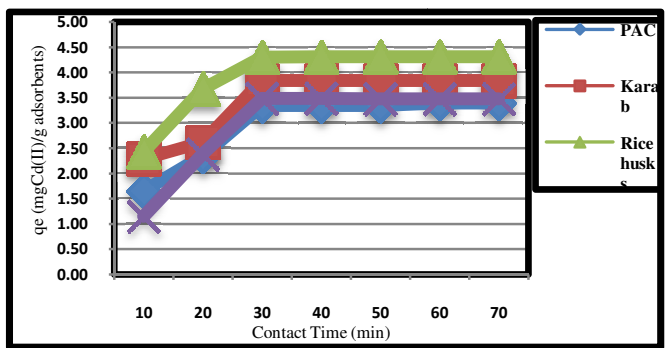

Figure (3): Effect of contact time on $\mathrm{Cd}(\mathrm{II})$ uptake for different materials.

\section{The effect of initial concentration:}

The effect of initial metal ion concentration on the breakthrough curves for each metal ion was investigated for all the systems.

Experiments were done at different initial concentrations of cadmium ion $(25,50,75$, 100 and $125 \mathrm{mg} / \mathrm{L}$ ), and the other conditions were kept the same $(\mathrm{pH}=5.5$, sorbent dosage $=1 \mathrm{~g} / 100 \mathrm{ml}$, contact time $=30 \mathrm{~min}$, stirring speed $=100 \mathrm{rpm}, \mathrm{Vol} .=100 \mathrm{ml}$ and particle size diameter $=0.425 \mathrm{~mm}$ ) by rice husks, karab, corncobs and PAC.

Figure (4) shows a linear increasing relation between the adsorbents uptake and initial $\mathrm{Cd}(\mathrm{II})$ concentrations.

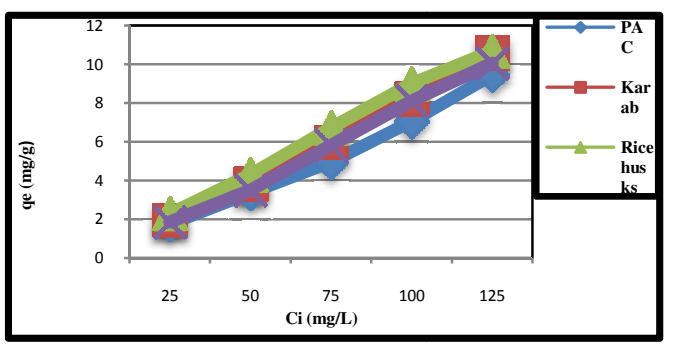

Figure (4): Effect of initial concentration on $\mathrm{Cd}(\mathrm{II})$ uptake for different materials.

The effect of stirring (mixing) speed:

The effect of stirring (mixing) the sorbent system on $\mathrm{Cd}(\mathrm{II})$ removal efficiency by different adsorbents was studied by varying the speed of mixing from 0 (with no-mixing as a control for comparison) to $200 \mathrm{rpm}$, 
while keeping the dosage of sorbent, the contact time and optimum $\mathrm{pH}$ as constants.

The $\mathrm{Cd}(\mathrm{II})$ uptake is increasing when the stirring speed is increasing from (0 to 100) rpm then remain constant for all adsorbents, as shown in Figure (5).

These results agreed with the results of Nomanbhay and Palanisamy, (2005). They found during their experiments, the removal efficiency for $\mathrm{Cr}$ (III) from aqueous solutions using chitosan coated oil palm shell charcoal increased by mixing, but the metal sorption capacity for the sorbent remained constant for agitation rates greater than $100 \mathrm{rpm}$.

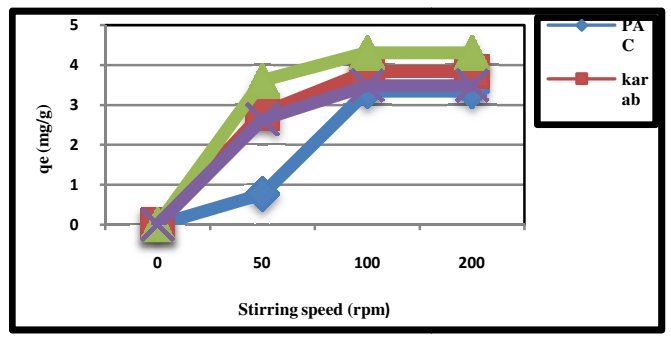

Figure (5): Effect of stirring speed on Cd(II) uptake for different materials.

\section{6- Effect of adsorbent particle size:}

One can notice from Figure (6) the effect of adsorbents particle size on $\mathrm{Cd}(\mathrm{II})$ uptake is negligible and cannot be recognized easily. From Figure (6), these differences are meaningless compared with other influential factors $(\mathrm{pH}$, dosage adsorbent, contact time, initial concentration and stirring (mixing) speed).

Roger, (2004) stated that the lignocellulosic materials have high ability to absorb water that allows accessibility of aqueous solutions to the cell wall components, therefore, the sorption of heavy metal ions by lignocellulosic materials does not depend on particle size. Furthermore, the influence of sorbent particle size on metal uptake seems to be a function of both the type of adsorbent and the metal ion.

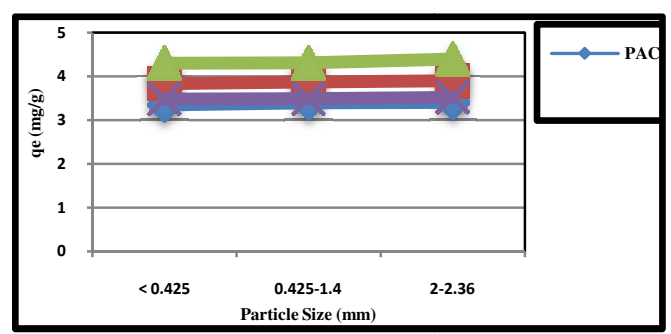

Figure (6): Effect of particle size diameter on $\mathrm{Cd}(\mathrm{II})$ uptake for different materials.
Equilibrium isotherm studies (Langmuir and Freundlich models):

\section{Langmuir model:}

In batch tests, Figures (7), (8), (9) and (10) reveal the plot of $\mathrm{C}_{\mathrm{f}} / \mathrm{q}_{\mathrm{e}}$ vs. $\mathrm{C}_{\mathrm{f}}$ for rice husks, karab, corncobs and PAC, respectively. These Figures show a straight line which means that the equilibrium data is correlated well with Langmuir equations. The constants of Langmuir equation for each media were calculated from the slope and the intercept of the straight line and listed in Table (1).

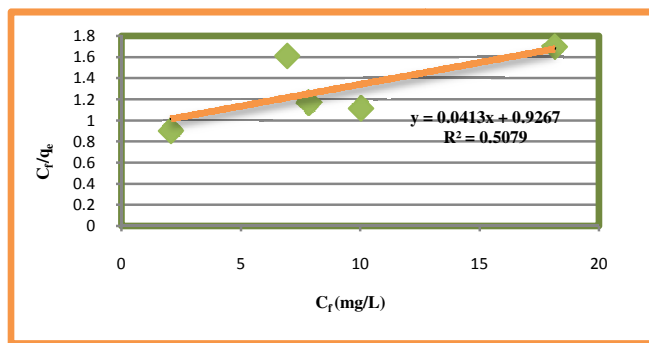

Figure (7): Plot of $\mathrm{C}_{\mathrm{f}} / \mathrm{q}_{\mathrm{e}}$ vs. $\mathrm{C}_{\mathrm{f}}$ for determination of Langmuir constants for rice husks

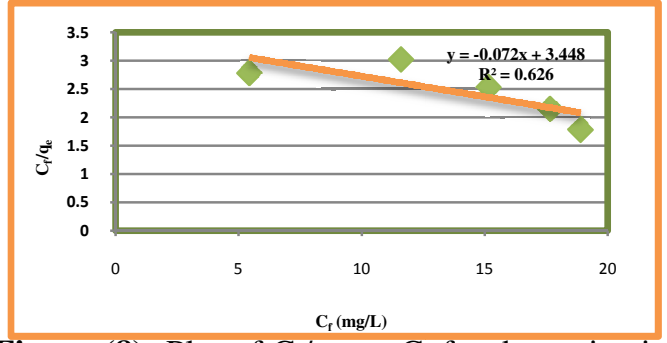

Figure (8): Plot of $\mathrm{C}_{\mathrm{f}} / \mathrm{q}_{\mathrm{e}} \mathrm{vs}$. $\mathrm{C}_{\mathrm{f}}$ for determination of Langmuir constants for karab.

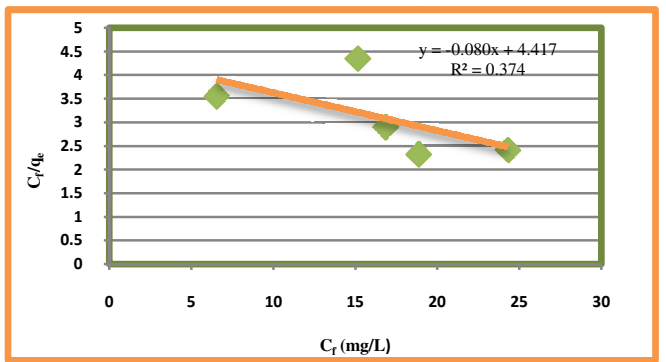

Figure (9): Plot of $\mathrm{C}_{\mathrm{f}} / \mathrm{q}_{\mathrm{e}}$ vs. $\mathrm{C}_{\mathrm{f}}$ for determination of Langmuir constants for corncobs.

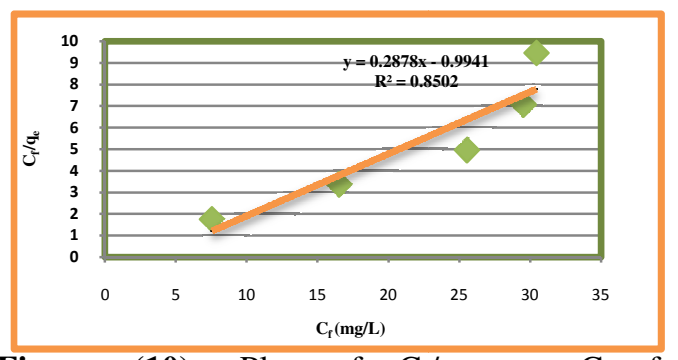

Figure (10): Plot of $\mathrm{C}_{\mathrm{f}} / \mathrm{q}_{\mathrm{e}}$ vs. $\mathrm{C}_{\mathrm{f}}$ for determination of Langmuir constants for PAC. 


\begin{tabular}{|c|c|c|c|c|}
\hline Media & $\mathbf{q}_{\max }$ & $\mathbf{b}$ & $\mathbf{R}^{2}$ & Equation \\
\hline PAC & 3.4843 & 0.994 & 0.85 & $\mathrm{q}_{\mathrm{e}}=3.4843 * 0.994 \mathrm{C}_{\mathrm{f}} /\left(1+0.994 \mathrm{C}_{\mathrm{f}}\right)$ \\
\hline Karab & 37.037 & 3.448 & 0.626 & $\mathrm{q}_{\mathrm{e}}=37.037 * 3.448 \mathrm{C}_{\mathrm{f}} /\left(1+3.448 \mathrm{C}_{\mathrm{f}}\right)$ \\
\hline Rice husks & 24.39 & 0.0413 & 0.508 & $\mathrm{q}_{\mathrm{e}}=24.39 * 0.0413 \mathrm{C}_{\mathrm{f}} /\left(1+0.0413 \mathrm{C}_{\mathrm{f}}\right)$ \\
\hline Corncobs & 12.5 & 4.417 & 0.374 & $\mathrm{q}_{\mathrm{e}}=12.5 * 0.4 .417 \mathrm{C}_{\mathrm{f}} /\left(1+4.417 \mathrm{C}_{\mathrm{f}}\right)$ \\
\hline
\end{tabular}

Table (1): Constant values of Langmuir equation and the equation for each media.

\section{$>$ Freundlich model:}

Figures (11), (12), (13) and (14) illustrate the plotting of $\log \mathrm{q}_{\mathrm{e}} \mathrm{vs} . \log \mathrm{C}_{\mathrm{f}}$ for rice husks, karab, corncobs and PAC, respectively. These Figures show a straight line (Freundlich adsorption isotherm) which means that the equilibrium data is correlated well with Freundlich equation. The constants for Freundlich equation were calculated from the slope and intercept of the straight line.

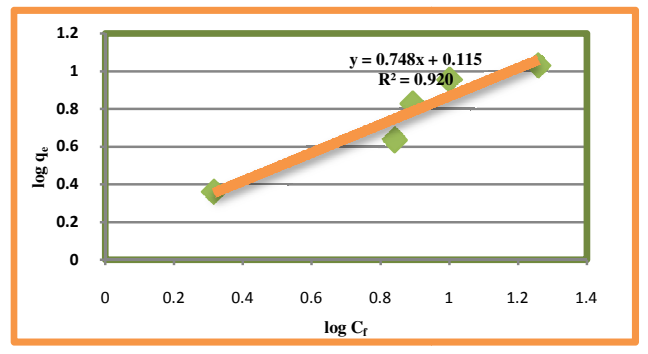

Figure (11): Plot of $\log q_{e}$ vs. $\log C_{f}$ for determination of Freundlich constant for rice husks.

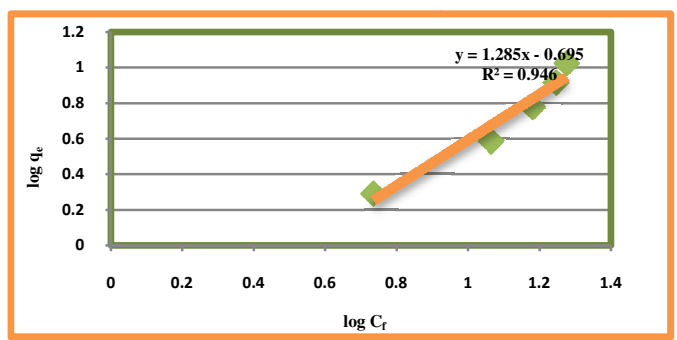

Figure (12): Plot of $\log \mathrm{q}_{\mathrm{e}}$ vs. $\log \mathrm{C}_{\mathrm{f}}$ for determination of Freundlich constant for karab.

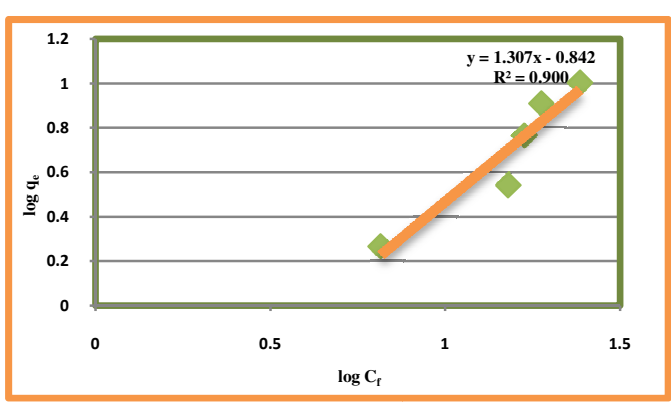

Figure (13): Plot of $\log q_{e}$ vs. $\log C_{f}$ for determination of Freundlich constant for corncobs.

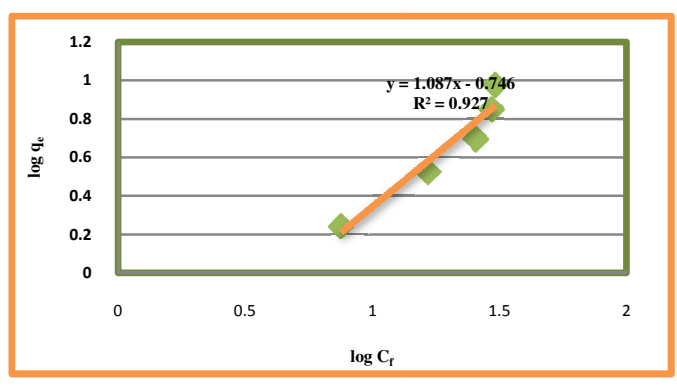

Figure (14): Plot of $\log \mathrm{q}_{\mathrm{e}}$ vs. $\log \mathrm{C}_{\mathrm{f}}$ for determination of Freundlich constant for PAC.

\begin{tabular}{|l|l|l|l|l|}
\hline Media & $\boldsymbol{K}_{f}$ & $\mathbf{1 / n}$ & $\boldsymbol{R}^{2}$ & Equation \\
\hline PAC & 0.18 & 1.087 & 0.927 & $\mathrm{q}_{\mathrm{e}}=0.18 \mathrm{C}_{\mathrm{f}}^{1.087}$ \\
\hline Karab & 0.202 & 1.285 & 0.946 & $\mathrm{q}_{\mathrm{e}}=0.202 \mathrm{C}_{\mathrm{f}}^{1.285}$ \\
\hline Rice husks & 1.3 & 0.748 & 0.92 & $\mathrm{q}_{\mathrm{e}}=1.3 \mathrm{C}_{\mathrm{f}}^{0.748}$ \\
\hline Corncobs & 0.144 & 1.307 & 0.9 & $\mathrm{q}_{\mathrm{e}}=0.144 \mathrm{C}_{\mathrm{f}}^{1.307}$ \\
\hline
\end{tabular}

Table (2): Constant values of Freundlich equation and the equation for each media.

\section{Conclusions:}

Several sorption were studied and considered by this research and here below, the main conclusions that were obtained from batch tests:

1- Rice husks, palms karab and corncobs are more effective to remove cadmium from synthetic wastewater than activated carbon that used in batch system.

Rice husks $>$ palm karab $>$ corncobs $>$ PAC.

2- Optimum conditions for $\mathrm{Cd}(\mathrm{II})$ uptake capacity were $\mathrm{pH}$ of solution 5.5, for adsorbent dosage $1 \mathrm{~g}$ adsorbent $/ 100 \mathrm{ml}$ of $\mathrm{Cd}(\mathrm{II})$, contact time 30min, initial 
concentration $125 \mathrm{mg} / \mathrm{L}$ and mixing (stirring) speed $100 \mathrm{rpm}$.

3- The Cd (II) uptake rate was not affected by particle size of adsorbents.

4- The equilibrium isotherm for the above systems is well represented by Freundlich model with high correlation coefficient (0.927, 0.946, 0.92 and 0.9) for PAC, rice husks, karab and corncobs.

5- Rice husks can be used instead of activated carbon in wastewater treatment plant for the removal of Cd (II).

\section{References:}

Aksu, Z., Gönen, F. and Demircan, Z. (2002). "Biosorption of chromium (VI) ions by Mowital (R) B30H resin immobilized activated sludge in a packed bed: comparison with granular activated carbon", Process Biochem, 8, pp. 175-186.

Alloway, B.J. and Ayres, D.C. (1997). "Chemical principals of environmental pollution", Second Edition, Blackie Academic and Professional, London.

Al-Najar, J.A.A. (2009). "Removal of heavy metals by adsorption using activated carbon and kaolinite", Ph.D. Thesis, University of Technology.

Cossich, E.S., Tavares, C.R.G. and Ravagnani, T.M.K. (2002). "Biosorption of chromium (III) by sargassum sp. biomass", Electronic Journal of Biotechnology (EJB), Vol. 5, No. 2.

Desi, I., Nagymajtenyi, L. and Schulz, H. (1998). "Behavioural and neurotoxicological changes caused by cadmium treatment of rats during development". J. Appl. Toxicol., 18, pp. 63-70.

Emani, P., Teresa, C.S., Maria, A.S., Oswaldo, K. and David, M. (2003). "Review heavy metal-induced oxidative stress in algae". Journal of Phycology, 39(6), pp. 1008-1011.

Metcalf \& Eddy, Inc., (2003). "Wastewater engineering: treatment and reuse", $4^{\text {th }}$ Edition, Tata McGraw-Hill
Publishing company limited, New Delhi.

Nomanbhay, S.M. and Palanisamy, K. (2005). "Removal of heavy metal from industrial wastewater using chitosan coated oil palm shell charcoal", Electronic Journal Of Biotechnology ISSN:0717-3458, Environmental Biotechnology, Vol. 8, No. 1, April $15^{\text {th }}$. www.ejbiotechnology.info/content/v ol8/issue 1/full/7/reprint.html

Roger, R. (2004), "Water decontamination", McGraw-Hill Yearbook of Science and Technology, New York: McGraw-Hill, pp. 372-373.

Said, A.G. (2010). "Biosorption of Pb (II) ions from aqueous solutions onto rice husk and its ash", Journal of American science, Vol.6 (10), pp.143-150.

Sayed, G.O., Dessouki, H.A. and Ibrahim, S.S. (2010). "Biosorption of Ni (II) and $\mathrm{Cd}$ (II) ions from aqueous solutions onto rice straw", Chemical Science Journal, Vol., CSJ-9.

Sulaymon, H.A. and Abdul-Hameed, H.M. (2010). "Competitive adsorption of cadmium lead and mercury ions onto activated carbon in batch adsorber", J. Int. Environmental Application \& Science, 5 (4), pp. 491-513.

Terry, P.A. and Stone, W. (2002), "Biosorption of cadmium and copper contaminated water by scenedesmus abundans", Chemosphere, 47, pp.249-255.

Tilaki, R.A.D., Mahvi, A.H., Shariat, M. and Nasseri, S. (2004), "Study of cadmium removal from environmental water by biofilm covered granular activated carbon", Iranian J. Pupl. Health, Vol. 33, No.4, pp. 43-52.

Volesky, B. and Naja, G. (2005), "Biosorption: Application Strategies", www.biosorption.mcgill.ca. 
تعثبر العناصر الثقيلة (heavy metals) من المواد الملوثة و السامة للمواد السطحية. إن المصادر الرئيسية للعناصر

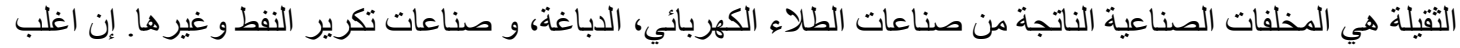

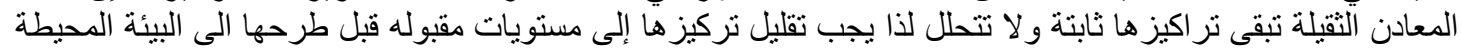

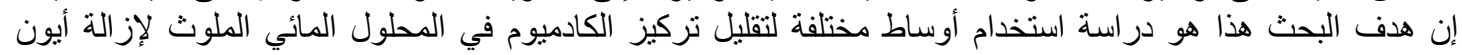

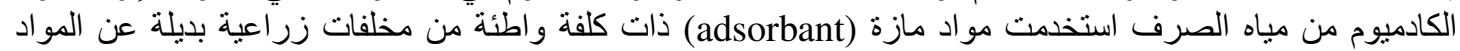
المازة التقليدية ذات الكلف العالية 